\title{
PERANCANGAN SISTEM INFORMASI DATA BIBIT PADA BALAI PENYULUHANPERTANIAN PERIKANAN DAN KEHUTANAN (BP3K) KEC. SITINJAU LAUT
}

\author{
Heru Saputra ${ }^{1)}$, Ilfa Stephane ${ }^{2)}$ \\ ${ }^{1,2}$ Sistem Informasi, STMIK Indonesia Padang, Jl. Khatib Sulaiman Dalam No. 1. Padang \\ email: h3ru.saputra@gmail.com, ilfastephane@gmail.com
}

\begin{abstract}
BP3K districts Sitinjau Laut is a regional unit that focuses on the field ofrejuvenation, fisheries and forestry agriculture. \&quot; When do data processing BP3Kstill using input data into the ledger and do not have a computerized data storagesystem that is able to edit or reprocess the data in the store so often experiencedelays and errors in data search and presentation of receipts / reports. Based onthe above problems it is proposed application of the application programdeveloped into an application program with programming language andintegrated with database. The results achieved is a computerized databaseinformation system design that can facilitate the BP3K in processing the data,especially the problem of seeds either incoming seeds or distribution of seeds andprovide reports quickly and on time. With the constructionof this computer-based applications, it is expected that all existing constraints canbe resolved properly so as to realize an effective and efficient system.
\end{abstract}

Keywords : rejuvenation, fisheries and forestry agriculture,database

\begin{abstract}
Abstrak
BP3K kecamatan setinjau laut merupakan badan unit daerah yang fokus di bidangpenyulahan, pertanian perikanan dan kehutanan. "Dalam melakukan pengolahandata BP $3 K$ masih menggunakan penginputan data ke dalam buku besar dan belummemiliki suatu sistem penyimpanan data secara komputerisasi yang mampumengedit atau mengolah kembali data yang di simpan sehingga sering mengalamiketerlambatan dan kesalahan dalam pencarian data dan penyajian resi/laporan". Berdasarkan permasalahan di atas maka diusulkan penerapan program aplikasiyang dikembangkan menjadi sebuah program aplikasi dengan bahasapemrograman dan terintegrasi dengan database. Hasil yang dicapai yaituberupa sebuah rancangan sistem informasi terkomputerisasi berbasis databaseyang dapat memudahkan pihak BP3K dalam mengolah data khususnya masalahbibit masuk atau penyaluran bibit dan memberikan laporan secaracepat dan tepat waktu. Dengandibangunnya aplikasi berbasis komputer ini, diharapkan semua kendala yang adadapat teratasi dengan baik sehingga terwujud sistem yang efektif dan efisien.
\end{abstract}

Kata Kunci : penyuluhan, pertanian, kehutanan, database

\section{PENDAHULUAN}

Data yang dibutuhkan oleh suatu Instansi atau organisasi tepatnya pada Balai Penyuluhan Pertanian Perikanan dan Kehutanan (BP3K) sering ditemui dalam jumlah yang besar dan ini tergolong penting karena suatu waktu akan disajikan kedalam bentuk informasi laporan untuk pihak yang terkait sehingga perlu suatu sistem informasi yang menggunakan peralatan modern. Instansi atau organisasi membutuhkan komputer yang dapat menangani pengolahan data dalam jumlah yang besar serta memperkecil kesalahan yang dilakukan. Suatu Instansi atau organisasi hendaknya memilih suatu sistem informasi yang akan membantu dalam menyediakan akses pelayanan kepada publik secara efektif dan efisien Pada penelitian ini, di bahas tentang bagaimanamerancang sistem pengolahan data diBalai Penyuluhan Pertanian Perikanan dan Kehutanan (BP3K)Kec. Sitinjau Laut. Balai Penyuluhan Pertanian Perikanan dan Kehutanan (BP3K) merupakan salah satu Instansi yang berasal dari kabupaten 
Kerinci provinsi Jambi. Dalam pengolahan data, Balai Penyuluhan Pertanian Perikanan dan Kehutanan (BP3K) masih menggunakan sistem manual seperti pencatatan data ke dalam buku besar, hal ini kurang tepat dan efektif karena banyaknya data yang akan diolah olehBP3K.Denganadanyasistem manual

sekaranginiterjadinyabanyakkendalasepertidup likasi data atau persamaan antara satu data dengan data lainya yang berdampak dan beresiko penerimaan data bibitbagimasyarakatterjadidua kali penerimaan,karena Instansi Balai Penyuluhan Pertanian Perikanan dan Kehutanan (BP3K) belum menggunakan primary key untuk menentukan penerimaanbibit. Kendala selanjutnya yang terjadi pada Instansi Balai Penyuluhan Pertanian Perikanan dan Kehutanan (BP3K) yaitu data yang telah dicatat tidak bisa dilakukan pengolahan kembali secara bersih dan cepat, hal ini berdampak dan beresiko pada laporan yang masih menggunakan buku besar.Lambatnya proses pencarian data di dalam buku besar, karena banyaknya data, hal ini bisa menghabiskan waktu untuk pencarian data dan melampirkan

BedasarkanpenjelasandiaatasmakaBalai

Penyuluhan Pertanian Perikanan dan

Kehutanan

(BP3K)perlumenggunakansisteminformasi

yang dapatmembantudalam proses pengolahandatanyasecaracepatdanaman.

\section{METODE PENELITIAN}

Tahap yang dilakukan pada penelitianini adalah yang pertama tahap perencanaan. Pada tahap perencanaan penulis memcoba melakukan identifikasi masalah yang terjadi kemudian, studi literatur terkait dengan penelitian ini, pengumpulan dan penetapan data yang digunakan untuk membangun sistem informasi Balai Penyuluhan Pertanian Perikanan dan Kehutanan (BP3K). Tahap selanjutnya adalah melakukan perancangan suatu sistem yang menggunakan konsep System Development Life Cycle(SDLC) yang terdiri dari analisis, desain dan implementasi.

\section{TINJAUAN PUSTAKA}

\section{Pengertian Perancangan}

Perancangan adalah langkah awal dalam membuat suatu sistem. Menurut (Subhan.
M,2012), perancangan adalah proses pengembangan spesifikasi baru berdasarkan rekomendasi hasil analisissistem. Sedangkan menurut (A. Bahra, 2005), tahapan perancangan memiliki tujuan untuk mendesainsistem baru yang dapat menyelesaikan masalah-masalah yang dihadapi perusahaan yangdiperoleh dari pemilihan alternatif sistem yang terbaik. Dan menurut (ilfa stephane, heru saputra,2017), perancangan adalahproses pengembangan spesifikasi sistem baru berdasarkan hasil rekomendasi analisissistem.

\section{Pengertian Sistem}

Sistem dapat didefinisikan sebagai suatu jaringan kerja dari prosedur-prosedur yang saling berhubungan, berkumpul bersama-sama untuk melakukan suatu kegiatan atau untukmenyelesaikan suatu sasaran tertentu (ilfa stephane, heru saputra,2017). Menurut (ilfa stephane, heru saputra,2017)sistem adalah sekelompok unsur yang erat hubungannya satu dengan yang lain,yang berfungsi bersamasama untuk mencapai tujuan tertentu. Sedangkan menurut (ilfa stephane, heru saputra,2017),sistem adalah sebuah tatanan (keterpaduan) yang terdiri atas sejumlah komponenfungsional dengan satuan fungsi dan tugas khusus yang saling berhubungan dan secarabersama-sama bertujuan untuk memenuhi suatu proses tertentu. Dengan demikian, secara umum sistem dapat didefinisikan sebagai kumpulan hal atauelemen yang saling bekerja sama atau yang dihubungkan dengan cara-cara tertentusehingga membentuk satu kesatuan untuk melaksanakan suatu fungsi guna mencapai suatutujuan (ilfa stephane, heru saputra,2017).

\section{Pengertian Informasi}

Menurut (T. Sutabri 2012)informasi adalah hasil pengolahan data sehingga menjadi bentuk yang penting bagi penerimanya dan mempunyai kegunaan sebagai dasar dalam pengambilan keputusanyang dapat dirasakan akibatnya secara langsung saat itu atau secara tidak langsung padasaat mendatang. Informasi adalah data yang telah diproses kedalam suatu bentuk yang mempunyai arti bagisi penerima dan mempunyai nilai nyata dan terasa bagi keputusan saat itu atau keputusanmendatang (ilfa stephane, heru saputra,2017). 


\section{Sistem Informasi}

Sistem informasi adalah suatu sistem di dalam suatu organisasi yang mempertemukan kebutuhan pengolahan transaksi harian yang mendukung fungsi operasi organisasi yangbersifat manajerial dengan kegiatan strategi dari suatu organisasi untuk dapat menyediakan

laporan-laporan yang diperlukan oleh pihak luar tertentu (ilfa stephane, heru saputra,2017). Menurut (ilfa stephane, heru saputra,2017),sistem informasi adalah kombinasi antara prosedur kerja, informasi, orang, danteknologi informasi yang diorganisasikan untuk mencapai tujuan dalam sebuah organisasi.Sedangkan menurut (ilfa stephane, heru saputra,2017), sistem informasi merupakan kumpulan dari perangkat keras danperangkat lunak komputer serta perangkat manusia yang akan mengolah datamenggunakan perangkat keras memegang peranan yang penting dalam sistem informasi.

Data yang akan dimasukkan dalam sebuah sistem informasi dapat berupa formulirformulir,prosedur-prosedur dan bentuk data lainnya.

\section{Balai Penyuluhan Pertanian Perikanan dan Kehutanan (BP3K)}

Balai Penyuluhan Pertanian (BPP) Sitinjau Laut saat ini sebagaimana diatur dalam UUNomor 16 Tahun 2006 tentang Sistem Penyuluhan Pertanian Perikanan dan Kehuatanan(SP3K) bahwa pada tingkat Kecamatan kelembagaan penyuluh disebut Balai PenyuluhanPertanian Perikanan dan Kehutanan (BP3K) dan dengan berdasarkan Surat Keputusan BupatiTahun 2011 Balai Penyuluhan Pertanian (BPP) berubah nama menjadi Balai PenyuluhanPertanian, Perikanan dan Kehutahan (BP3K) Kecamatan Sitinjau Laut. Balai Penyuluhan inisejak terbentuknya telah terjadi beberapa kali pergantian pimpinan tercatat sejakdifungsikannya untuk menjadi wadah penyuluh sebagai basis penyuluhan ditingkat kecamatan,

\section{HASIL DAN PEMBAHASAN}

\section{Analisis Sistem Baru}

Analisis sistem yang dirancang memiliki tujuan untuk menghasilkan suatu bentuk rancangan baru yang berguna untuk mengatasi kendala atau kelemahan yang dihadapi dalampengolahan data bibit pada Balai
Penyuluhan Pertanian Perikanan dan Kehutanan (BP3K). Analisis dan perancangan sistem yang baru ini diharapkan bisa digunakan untuk mendukung semua kegiatanpengolahan data sampai dengan pembuatan laporan yang ditujukan kepada pimpinan dan masyarakat.

\section{Aliran Sistem Baru}

Tahapanawal dari suatu proses perencanaan sistem informasi yang baru adalah melakukan identifikasi secara lengkap terhadap tujuan,sasaran, dan kendalayang di hadapiolehBalai Penyuluhan Pertanian Perikanan dan Kehutanan (BP3K).Rancangan sistem yang baru ini dapat memberikan kemudahan antara informasi yang tersedia dengan penggunanya. Dengan terbentuknya sistem informasi yang baruini diharapkan bisa mendukung kegiatanstaf BP3K sehingga dapat memberikan informasi yang berkualitas bagi kelompoktanidankepala BP3K.Penyajian sistem informasi yang baru akan langsung dilakukan oleh sistem. Berbeda dengan sistem informasi yang lama dimana proses pembuatan dan pengolahan data hanya dapat diketahui pihak-pihak yang langsung terlibat dalam proses tersebut. Berikut ini adalah gambar aliran sistem informasi yang baru:

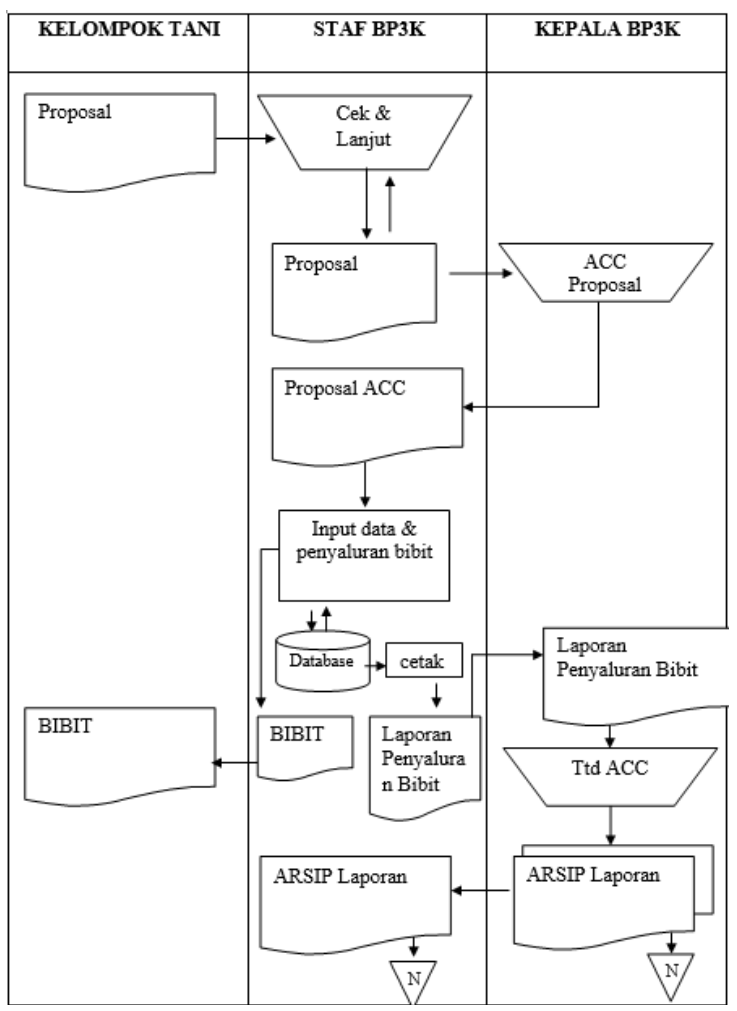

Gambar 1.Analisis Sistem Baru

Keterangan gambar: 
Sistem yang dirancang terdiri dari 3 entitas yaitu kelompok tani, staf BP3K, dan kepala BP3K. setiap entitas memiliki peran masingmasing seperti penjelesan seperti dibawah ini:

a. Kelompok tani berperan memberikan proposal yang akan dicek dan ditindaklanjuti oleh staf BP3K.

b. Staff BP3Kmenginputan proposal dan pemrosesan data dari kelompok tani yang yang telah diacc oleh kepala BP3K.Dan menghasilkan laporan penyaluran bibit dan bibit yang akan diserahkan ke kelompok tani sesuai permintaan bibit yang diminta. Laporan penyaluran bibit kemudian diarsipkan setelah di tandatangan oleh kepala BP3K. Data yang sudah diinput dan di proses akan tersimpan kedalam database.

c. Kepala BP3K berperan mengacc proposal yang diterima oleh staf BP3K setelah melalui proses dan menandatangani laporan penyerahan bibit sebanyak 2 rangkap kemudian diserahkan kembali ke bagian staaf dan satu lagi sebagai arsip pimpinan.

\section{Hierarchy Input ProcessOutput (HIPO)}

Hierarchy Input Process Outputmerupakan alat perancangan untuk membuatrancangan dalam pengembangan sistem. Berikut adalah HIPO Sistem Informasi Balai Penyuluhan Pertanian Perikanan Dan Kehutanan (BP3K) Kec. Sitinjau Laut

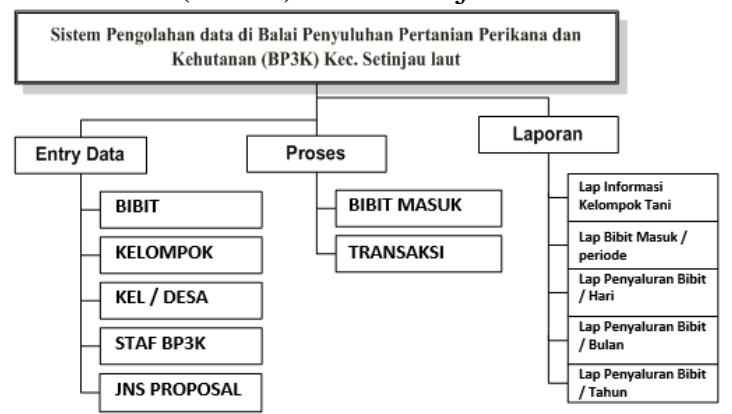

Gambar

2.SistemInformasiBalaiPenyuluhanPertani anPerikanan Dan Kehutanan (BP3K) Kec.

SitinjauLaut

\section{Context Diagram}

Context Diagrammerupakan alat bantu untuk melakukan suatu perancangan yang memperlihatkan suatu sistem secara umum. Pada bagian Context Diagramini, perancangan Balai Penyuluhan Pertanian Perikanan Dan Kehutanan (BP3K) Kec. Sitinjau Laut terdiri dari tiga entitas yang saling berinteraksi satu dengan yang lainnya. Berikut digambarkan bentuk Context Diagramyang dirancang pada analisa dan perancangan Balai Penyuluhan Pertanian Perikanan Dan Kehutanan (BP3K) Kec. Sitinjau Laut.

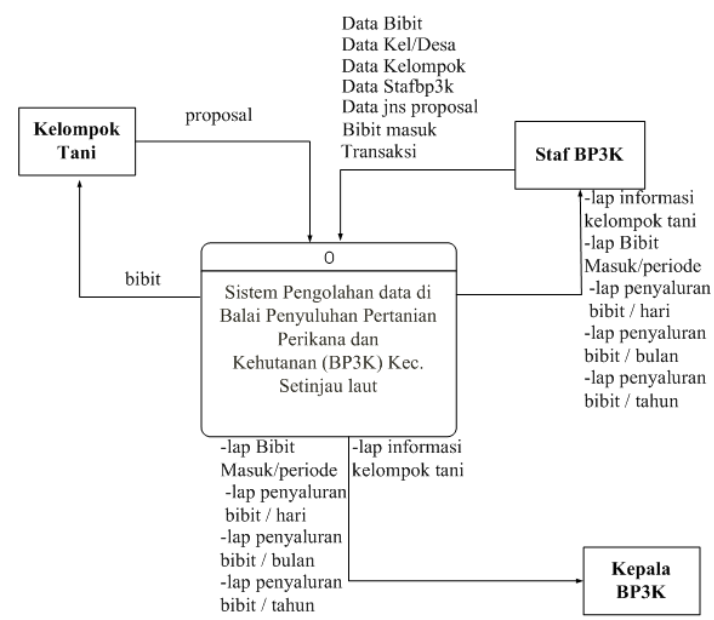

Gambar 3. Context Diagram Sistem Informasi

BalaiPenyuluhanPertanianPerikanan Dan Kehutanan (BP3K) Kec. SitinjauLaut.

\section{Data Flow Diagram (DFD)}

Data Flow Diagramadalah diagram yang menguraikan proses padaContext Diagramdalam bentuk yang lebih detail menyangkut entri, proses dan penyerahan laporan pada sistem. Berikut gambaran DFD untuk Sistem Informasi LKMA Prima Agung yang baru

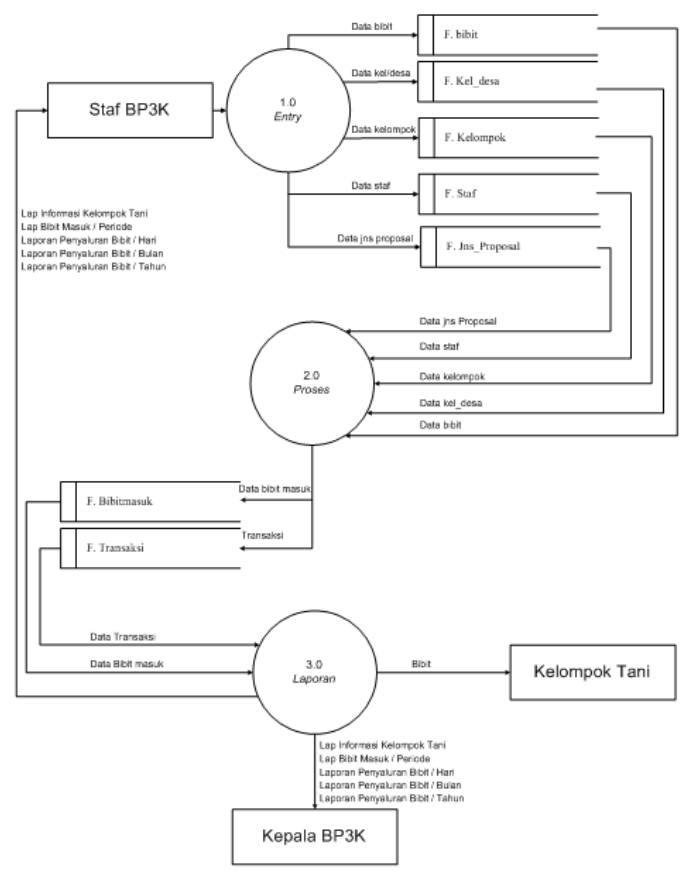


Gambar 4. Data Flow Diagram Sistem Informasi

BalaiPenyuluhanPertanianPerikanan Dan Kehutanan (BP3K) Kec. SitinjauLaut.

\section{Entity Relationship Diagram(ERD)}

Entity Relationship Diagram(ERD) Suatu diagram yang menggambarkan hubungan antara entity-entity yang terdapat dalam suatu Database disebut entity relationship diagram dari Sistem Informasi Balai Penyuluhan Pertanian Perikanan Dan Kehutanan (BP3K) Kec. Sitinjau Laut

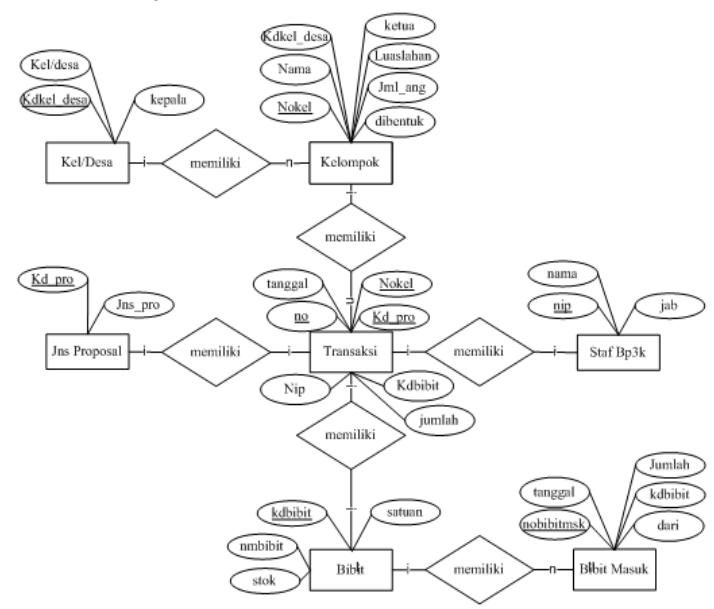

Gambar 5.Entity Relationship Diagram(ERD) Sistem Informasi

BalaiPenyuluhanPertanianPerikanan Dan Kehutanan (BP3K) Kec. SitinjauLaut.

\section{Rancangan Input}

Rancangan inputdibuat untuk menginputkan data-data sesuai dengan form ke dalam database. Adapun rancangan inputdapat dilihat dari gambar berikut
a. Form Input Data Bibit
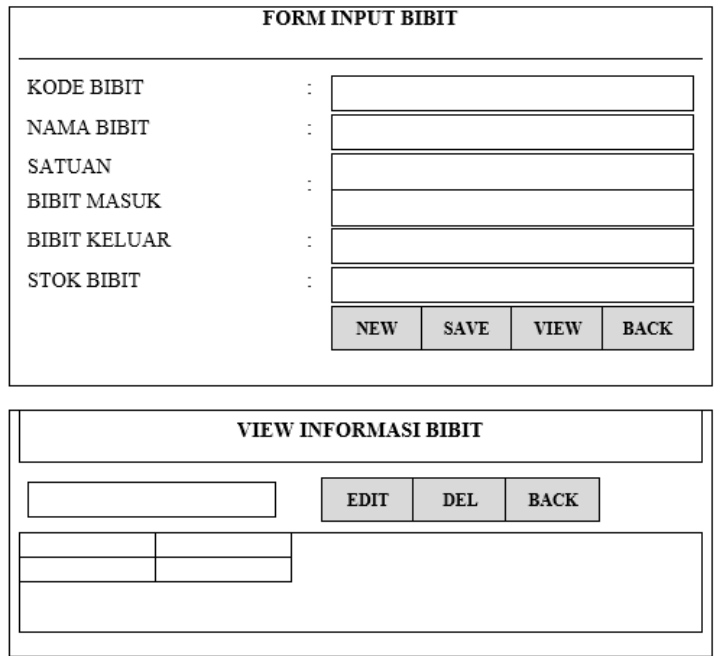

Gambar 6.Rancangan Input Data Bibit

b. Form Input Data Kelompok
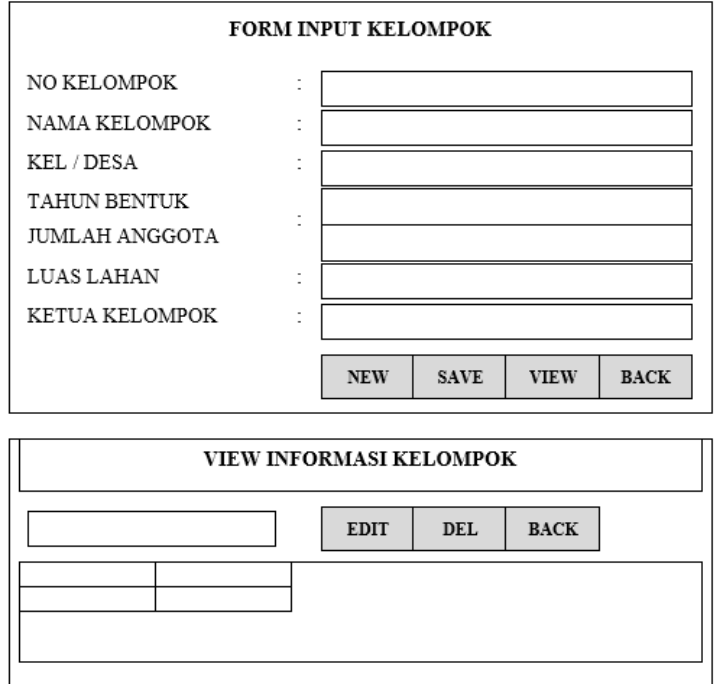

Gambar 7.Rancangan Input Data Kelompok

c. Form Input Data Kelurahan/Desa

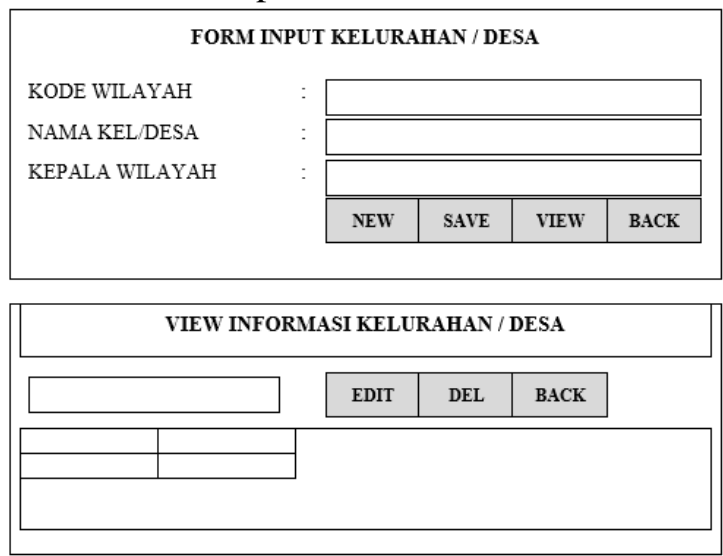


Gambar 8.Rancangan Input Data Kelurahan/Desa

d. Form Input Data Staff

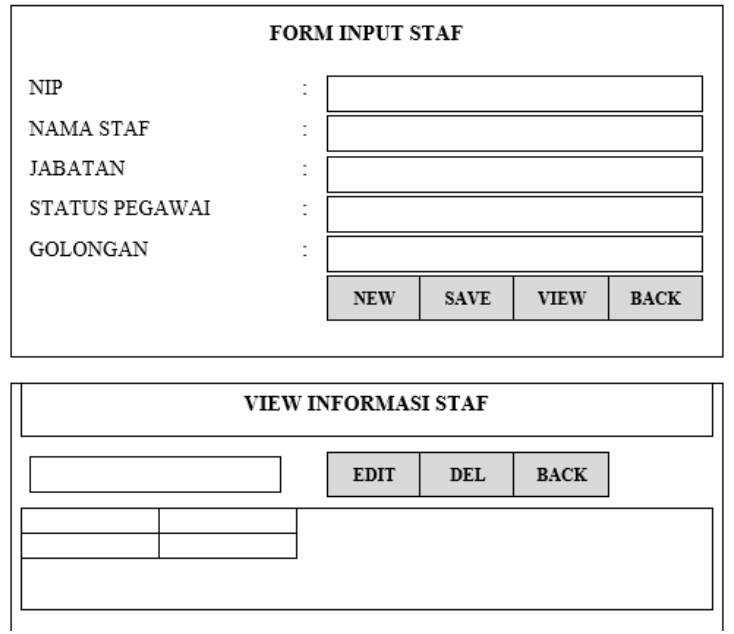

Gambar 9.Rancangan Input Data Staff

e. Form Input Data Jenis Proposal
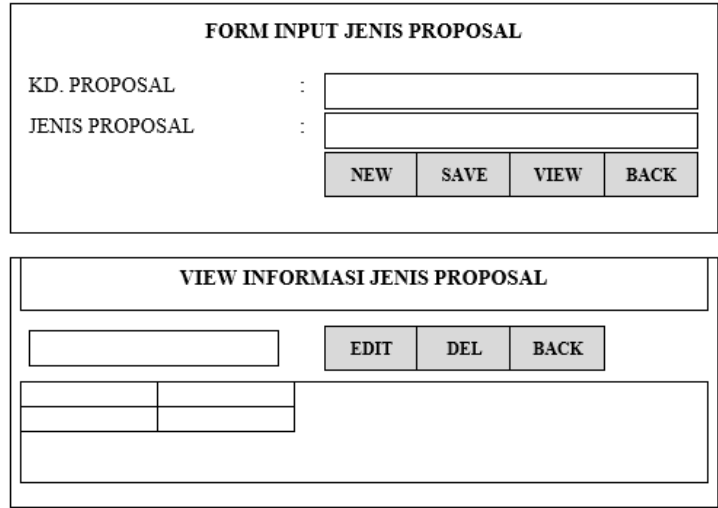

Gambar 10.Rancangan Input Data Jenis Proposal

\section{Rancangan Proses}

Rancangan Proses merupakan pengolahan dari suatu sistem yang akan diproses

a. Form Proses Bibit Masuk

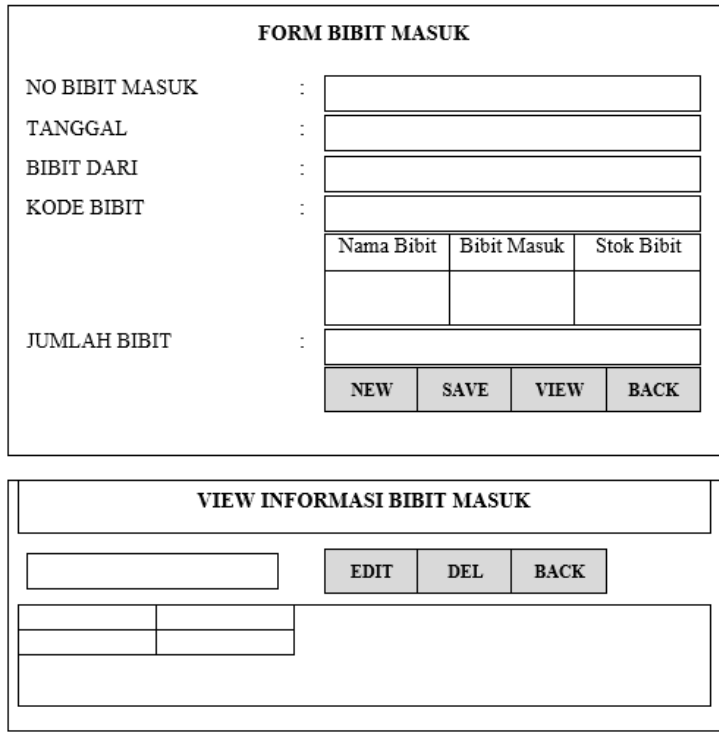

Gambar 11.Rancangan Form Proses Bibit Masuk

b. Form Proses Transaksi
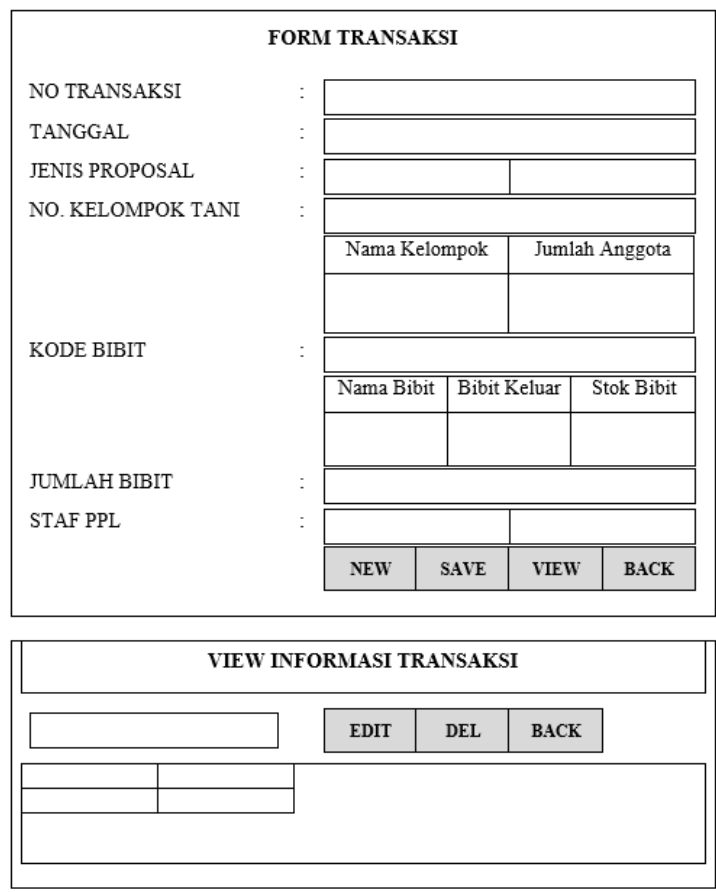

Gambar 12.Rancangan Form Proses Transaksi

\section{Rancangan Output}

Rancangan outputmerupakan tampilan atau keluaran dari hasil yang diinputkan

a. Rancangan Laporan Informasi kelompok Tani 


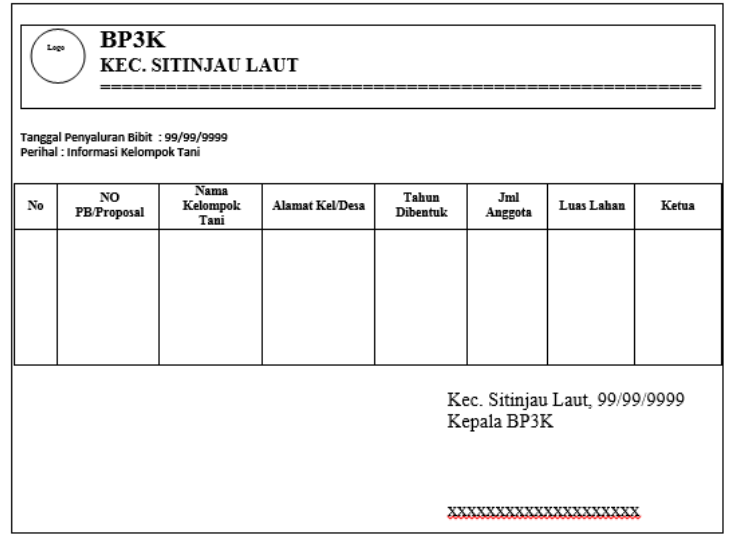

Gambar 13.Laporan Informasi kelompok Tani

b. Rancangan Laporan Bibit Masuk

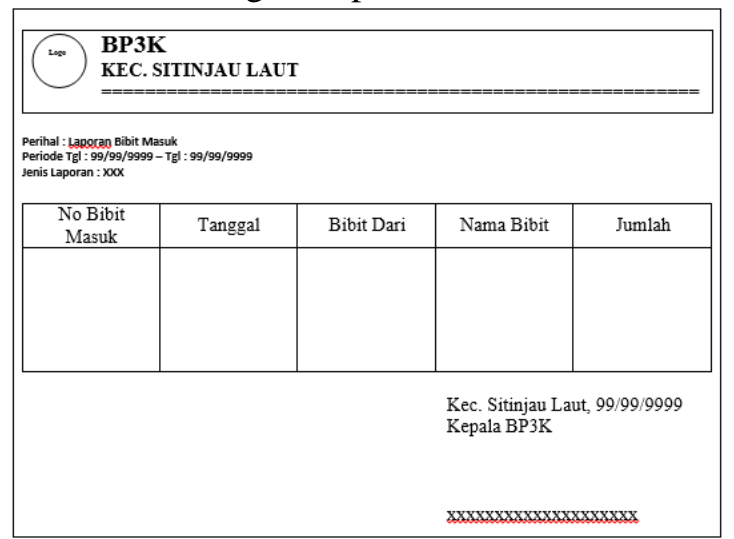

Gambar 14.Laporan Bibit Masuk

c. Rancangan Laporan Penyaluran Bibit/Hari

\begin{tabular}{|c|c|c|c|c|c|c|c|}
\hline \multirow{2}{*}{\multicolumn{8}{|c|}{$\begin{array}{l}\begin{array}{l}\text { BP3K } \\
\text { KEC. SITINJAU LAUT } \\
===========\end{array} \\
\begin{array}{l}\text { Laporan Tanggal : } 99 / 99 / 9999 \\
\text { Perihal : Laporan Penyaluran Bibit / hari }\end{array}\end{array}$}} \\
\hline & & & & & & & \\
\hline \multirow[t]{3}{*}{ No } & $\begin{array}{c}\text { Jenis } \\
\text { Proposal } \\
\end{array}$ & Kelompok & $\begin{array}{l}\text { Jumlah } \\
\text { Anggota }\end{array}$ & KelDesa & $\begin{array}{l}\text { Nama } \\
\text { Bibit }\end{array}$ & Jumlah & Staf PPL \\
\hline & & & & \multicolumn{4}{|c|}{$\begin{array}{l}\text { Kec. Sitinjau Laut, 99/99/9999 } \\
\text { Kepala BP3K }\end{array}$} \\
\hline & & & & \multicolumn{4}{|c|}{ 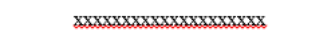 } \\
\hline
\end{tabular}

Gambar 15.Laporan Penyaluran Bibit/Hari

d. Rancangan Laporan Penyaluran Bibit/Bulan

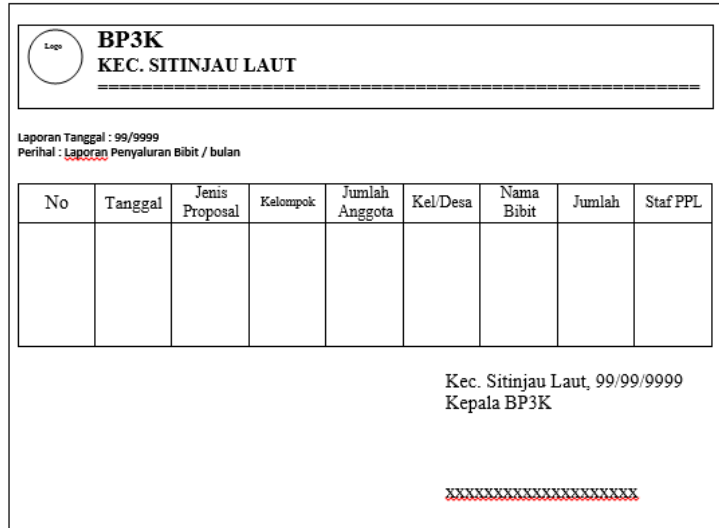

Gambar 16.Laporan Penyaluran Bibit/Bulan

e. Rancangan Laporan Penyaluran Bibit/Tahun

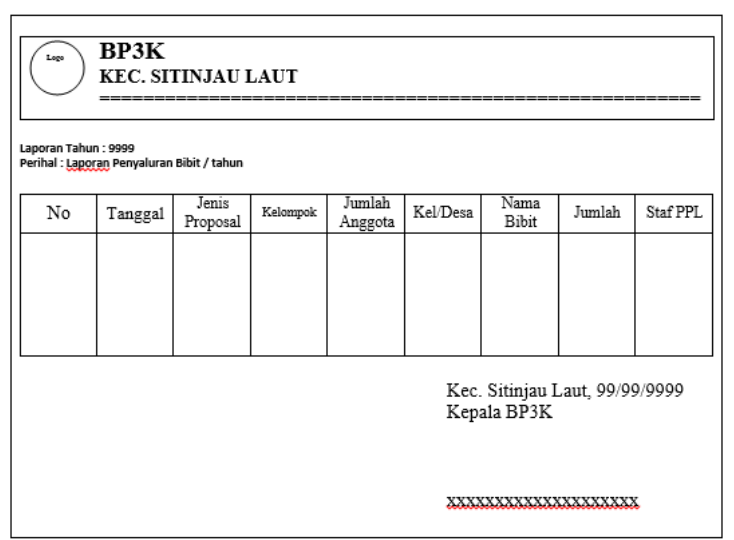

Gambar 17.Laporan Penyaluran Bibit/Tahun

\section{SIMPULAN}

Dengan adanya sistem pengolahan data bibit pada balai penyuluhanpertaninan perikanan dan kehutanan, maka diperoleh kesimpulan bahwa sistem yang lama memiliki kelemahan seperti seringterjadiduplikasi data dan kehilangan data karena tidak ada database dan backup data.Sedangkan dengan menggunakan sistem yang diusulkandapat memberikan kemudahan bagi petugas BP3K dalam melakukan pengolahan data data bibit karena telah menggunakan pemrogramandandatabase.

\section{DAFTAR RUJUKAN}

BAHRA.A,

2005.AnalisisdanDesainSistemInform asi.Yogjakarta: GrahaIlmu,

DESSLER, GARY. 2009.

ManajemenSumberDayaManusia. Jakarta: Penerbit PT.INDEKS 
KADIR, ABDUL. 2009. MembuatAplikasi Web dengan PHP + Database MySQL.Yogyakarta: Penerbit ANDI

NUGROHO, ADI. 2005. Rational Rose untukPemodelanBerorientasiObjek. Bandung: Penerbit INFORMATIKA

SAPUTRA AGUS dan FENI AGUSTIN.2011. Pemrograman CSS UntukPemula. Cirebon: Penerbit ELEX MEDIA KOMPUTINDO

SUBHAN.M,

2012.AnalisisPerancanganSistem.Jaka rta:LenteraIlmuCendekia.

SUTABRI. T, AnalisaSistemInformasi, Yogyakarta: Andi Offset, 2012

STEPHANE ILFA\&HERU SAPUTRA. 2017. PerancanganSistemInformasiLembaga KeuanganMikroAgrobisnis(LKMA) Prima AgungKanagarian Sungai Duo KecamatanSitiungKabupatenDharmasr aya.STMIK Indonesia Padang, Padang.

M. MUHAMAD , OKTAFIANTO. 2016. AnalisisdanPerancanganSistemInform asiMenggunakan Model Terstruktur: PenerbitAndi.

TOM \& ANGELA HATHAWAY. 2015. Data Flow Diagrams - Simply Put 